\title{
Correction to: inhibition of p38 MAPK activity leads to cell type-specific effects on the molecular circadian clock and time- dependent reduction of glioma cell invasiveness
}

\author{
Charles S. Goldsmith', Sam Moon Kim², Nirmala Karunarathna², Nichole Neuendorff ${ }^{3}$, L. Gerard Toussaint ${ }^{3}$, \\ David J. Earnest ${ }^{2,3,4,5^{*}}$ and Deborah Bell-Pedersen ${ }^{1,2,4}$
}

\section{Correction to: BMC Cancer (2018) 18:43 http://doi.org/10.1186/s12885-017-3896-y}

Following publication of the original article [1], we have been notified that the tagging of one of the author names was done incorrectly in the XML version of the paper. The online and pdf versions of this paper are not affected by the change. Original and corrected tagging can be seen below. The original article has been corrected.

- Incorrect name tagging: Last Name: Gerard Toussaint. First Name: L.

- Correct author name tagging: Last Name: Toussaint. Middle Name: Gerard. First Name: L.

\section{Author details}

${ }^{1}$ Interdisciplinary Program in Genetics, Texas A\&M University, College Station TX, Texas 77843, USA. ²Department of Biology, Texas A\&M University, College Station, Texas, TX 77843, USA. ${ }^{3}$ Department of Neuroscience and Experimental Therapeutics, Texas A\&M, Health Science Center, College of Medicine Bryan, Texas, TX 77807-3260, USA. ${ }^{4}$ Center for Biological Clocks Research, Texas A\&M University, College Station, Texas, TX 77843, USA. ${ }^{5}$ Interdisciplinary Program in Neuroscience, Texas A\&M University, College Station, Texas, TX 77843, USA.
Received: 28 December 2018 Accepted: 28 December 2018 Published online: 23 January 2019

\section{Reference}

. Goldsmith CS, et al. Inhibition of p38 MAPK activity leads to cell typespecific effects on the molecular circadian clock and time-dependent reduction of glioma cell invasiveness. BMC Cancer. 2018;18:43. https://doi. org/10.1186/s12885-017-3896-y.

* Correspondence: dpedersen@bio.tamu.edu; Dearnest@medicine.tamhsc.edu ${ }^{2}$ Department of Biology, Texas A\&M University, College Station, Texas, TX 77843, USA

${ }^{3}$ Department of Neuroscience and Experimental Therapeutics, Texas A\&M, Health Science Center, College of Medicine Bryan, Texas, TX 77807-3260, USA Full list of author information is available at the end of the article

(c) The Author(s). 2019 Open Access This article is distributed under the terms of the Creative Commons Attribution 4.0 International License (http://creativecommons.org/licenses/by/4.0/), which permits unrestricted use, distribution, and reproduction in any medium, provided you give appropriate credit to the original author(s) and the source, provide a link to the Creative Commons license, and indicate if changes were made. The Creative Commons Public Domain Dedication waiver (http://creativecommons.org/publicdomain/zero/1.0/) applies to the data made available in this article, unless otherwise stated. 